\title{
'Climate wars' claims disputed
}

The idea that climate change might be a trigger for social disorder, population migration and conflict has an impressive pedigree. The link was mooted in a 2003 report for the Pentagon on the nationalsecurity implications of climate change; by the Stern review on the economics of climate change, prepared for the UK government in 2006; and in the United Nations' post-conflict environmental assessment of Sudan in 2007, which suggested that climate change was an aggravating factor in the Darfur conflict.

But is there real proof of a link between climate change and civil war?

No, says Halvard Buhaug, a political scientist with the Peace Research Institute Oslo. In research published this week ${ }^{1}$, he finds almost no correlation between climatechange indicators, such as temperature and rainfall variability, and the frequency of civil wars over the past 50 years in subSaharan Africa - arguably the part of the world that is socially and environmentally most vulnerable to climate change. "The primary causes of civil war are political, not environmental," says Buhaug.

The analysis challenges a study published last year by Marshall Burke, an economist at the University of California, Berkeley, and colleagues, who reported a strong historical relationship between temperature and the incidence of civil war ${ }^{2}$. They found that the likelihood of armed conflict across the continent rose by some $50 \%$ in unusually warm years between 1981 and 2002.

Neither Burke nor Buhaug is giving any ground; each challenges the other's definition of 'civil war' and choice of climate data sets.

Given the many causes of unrest, it is not surprising that a meaningful correlation with climate is hard to pin down, says Hans Joachim Schellnhuber, director of the Potsdam Institute for
Climate Impact Research in Germany.

"This does not at all diminish the

importance of responding to climate change," adds Roger Pielke, a climate policy expert at the University of Colorado in Boulder. "But it does offer a stark warning about trying to use overly simplistic notions of cause and effect to advocate for such actions."

Quirin Schiermeier

1. Buhaug, H. Proc. Natl Acad. Sci. USA doi:10.1073/ pnas.1005739107 (2010).

2. Burke, M. B. et al. Proc. Natl Acad. Sci. USA 106, 20670-20674 (2009)

See go.nature.com/gcUcl4 for a longer version of this story.

\section{Correction}

The article 'Ecologists fear Antarctic krill crisis' (Nature 467, 15; 2010) incorrectly stated that North Korean ship owners are resistant to the idea of granting scientists access to commercial fishing vessels. It should have said 'South Korean'. 